\section{LAND ECONOMIC}

His grand picture is of course ECONOMIC, more precisely 'land economic'. ${ }^{1}$ His analytic approach to planning and urban management is ECONOMETRIC. He favours quantification and evidence. By giving us a dynamic way of thinking about urban quantities, he prepares planners for the expanding information and computer age. This contrasts with the SOCIOLOGICAL conception of a city whose mode of analysis would be ANTROPOLOGICAL favouring identity and values. Or, closer to home, an AESTHETIC conception that analyses and understands the cities in terms of URBAN DESIGN. The last-mentioned conception comes in for severe criticism throughout Bertaud's book. His claim is that the 'design'2 approach to understanding and managing cities has caused untold inefficiencies and price distortions in urban settlements worldwide.

Town and Regional Planning as a discipline has its roots in two historic traditions: AESTHETICS, being architectural and environmental psychology, and POLITICAL, with its two legs being law reforms in health and housing, and revolutionary utopian thought. This explains the almost exclusive preoccupation with 'physical appearance' and with 'politics' by planning's educational curricula.

Currently, the near absence of 'economic' training in planning schools is palpable. Micro-economics teaches shorthand concepts such as supply-demand. Said concepts

1 This is distinct from say Harry W. Richardson's "Regional and urban economics" (1978), Penguin Books) which attempts to bring 'distance' and 'location' into goods and services pricing theory.

2 He uses the word DESIGN, with its norms and standards, rather than PLANNING, because planning as such remains indispensable to the operations of his ECONOMIC city. 
may be abstract and by no means a precise calculator for commodity prices, but they do build a keen intuition for dynamism and for an appreciation of fluidity in the world. If unencumbered, prices trend towards equilibrium, resources tend to be allocated better than if done by a central authority, and so on. Planners are fully aware that cities are always in a state of flux, and yet are applying only static mechanisms such as regulations, policy, statutory plans, and so on for consideration. None of them cope with fluid or changing contexts. None of them cope with the 10000 choices ordinary people make in their lives. Bertaud steps into this gap by giving us a useful and concise 'urban economic model' with which to consider cities.

What is this ECONOMIC conception? In his model, cities are a spatial concentration of human beings for the primary purpose of 'work' and working together! Productivity 'per capita' rises tremendously when people work closely together, compared to when working in isolation. These natural efficiency gains are what hold urban systems together in the first place. The justification for accepting this view of the origin and purpose of cities is that primary cities in every national economy contribute a larger share of 'product' to national GDP than is their share of the nation's population. Or, seen from below, a doubling of a city's population leads to a $15 \%$ rise in productivity 'per capita' (p. 144). These findings have been near universal.

To optimise this 'working together', jobseekers and employers must find each other with the least amount of trouble. Skills and technology must connect with each other as the economy shifts and changes. Manual and skilled labourers must rapidly find the places at which they are needed, in the moment. To capture this idea, Bertaud refers to cities as "Labour Markets", ${ }^{3}$ and the overriding task of urban management must be to ensure that this marketplace of labour functions as efficiently as it can. If that gets done, urban

3 Nothing to do or be confused with the realms of 'labour unionisms' or 'labour legislation'. productivity is always enhanced.

This already makes us appreciate that urban growth (i.e. population increases) should neither be interfered with nor be wilfully boosted or suppressed. Where the labour marketplace does get interfered with, distortions result - its attempt to return to equilibrium gets blocked, and thus wages are artificially trapped at too high or too low a level!

\section{LAND CONSUMPTION}

Population increases require more space. Or, as family incomes increase, so more living space is demanded. The way this is supplied by a well-functioning market is via the "Land Consumption" process, as Bertaud calls it. It is the process whereby land is converted from raw land into human living space, or from low-density urban areas to high-density areas; 4 or from office buildings into residential units. In the capitalist world, this ongoing conversion process accounts for the ever (re)shaping of our cities. Where this is not the case ${ }^{5}$ huge inefficiencies get cast in stone, which market forces can only correct over many generations, if ever. The next task for urban managers is to ensure that 'land consumption' is permitted to operate smoothly. Again, this means lifting regulatory interferences (including any statutory spatial plans) or any bottlenecks that may arise.

Land prices and fluctuating people/ per hectare densities are mediators of the land-consumption process. These mechanisms continually match the supply of living space with the demand for it. Again, any encumbrances mean that the equilibrium cannot be (re)established properly, meaning that land prices are stuck either too high or low, as the case may be. Urban densities, in turn, are out of sync with what households and companies demand. Stated differently, living and working spaces are inefficiently 'allocated' when their demand cannot find its supply level. Bertaud offers an

4 Industrial and commercial, or workspace, is obviously similarly converted.

5 Among other examples, Bertaud uses apartheid South African cities to argue the point. important insight, namely that "land [is unlike a] commodity" (p. 222). If you have no money, you go without a cell phone; if you have no money, you still require a space to stay. This sets the land-pricing process apart from commodity-pricing theory of standard economics.

\section{LAND REGULATION}

As with a free-market economy, which is inconceivable without essential state regulation (on say contract enforcement; property rights enforcement, and so on), Bertaud's city cannot be built entirely by the free market. Land Consumption and Labour Markets only function when municipal governments supply those public goods that markets cannot provide. These are roads (or movement routes) and open space, and this is the core function of Planning. A second important function of Planning is to keep an eye firmly on the urban management tasks mentioned earlier. Planning must ensure that their operations continue smoothly in the face of urban scale increases, of changes in family income, and the arrival of new technologies. The book provides indicators whereby to monitor their functioning. Timeous interventions for sidestepping bottlenecks are essential to allow for a renewed round of productivity growth and efficiency.

Particularly appealing about the ECONOMIC view of the city to me is that it is 'democratic'. The choices people make: be it where to live and how much space to rent; what type of accommodation to build and where; what job to accept or decline; what mode of transport to use, and so on, all feed into a "... spontaneous spatial equilibrium created by the sum of uncoordinated, individual decisions ..." (p. 27). This balance is the most rational (re)allocation of space (as a resource) and, by extension, the most optimal form/shape for a city. Any policy proposal must be assessed against what it means for this automatically participative process. ${ }^{6}$ By that standard, a master

6 Bertaud is not arguing in favour of an absolute deregulation of urban space. 
plan would be undemocratic in that it takes upon itself all household and company decisions. It decides on behalf of the many. That has material implications (losses/costs) for those who are being decided for, and for urban form as a whole.

Bertaud's book gives several appealing models whereby to monitor cities. One looks at the role of state compared to the private sector in supplying space, and their relationship to population size. It is given in a very useful flow-chart format (p. 84). This helps judge how much urban expansion is required and what amount is the responsibility of the state. A second is a recapitulation of the classic location-theory models to predict land prices from the centre of a city (p. 98). These allow us to judge whether prices are 'right' in actuality (and with it whether densities are 'right' per location). His recapitulation deploys the models from a 'pricedetermining' angle, rather than a 'location-choice' point of view. This is really refreshing and useful for urban management. Thirdly, he offers very appealing and simple spatial indices for, urban mobility and affordability, which are essential for managing urban performance. Historically, urban economics served the 'firm' and its imperatives. Bertaud works in the service of urban managers.

\section{IMPLICATIONS AND LESSONS}

\subsection{Mobility}

The key to detecting faults and efficiencies in the labour market is by securing 'mobility'. In South Africa, the impulse has always been to bring jobs and residences into closer proximity, thereby minimising the cost and time expended on commuting. Since mobility is viewed as the antithesis hereof, it has been badly neglected. Bertaud would not disagree with this stance but thinks of mobility in much wider terms. For instance, if all people in a metropolitan area were employed within a 1-km radius of their home, and so could walk or cycle rather than commute to work, it would amount to an extreme 'labour-risk'. The reason for this is that, if the structure of the economy were to change for some reason, and jobs and skills were spatially redistributed as a consequence, the urban workforce would be unable to adjust. The labour market would be stalled. In Bertaud's terms 'mobility' is to city as 'circulation' is to the organism. Slow them down and death approaches. Mobility distributes energy (i.e. human labour) to where it is required in each moment, and a rapid enough reorganisation of the physical city to meet the new labour demands cannot be brought about by the state or private sector. Moreover, easy access to alternative jobs by workers allows them much greater choices associated with job satisfaction and wages. Employers obtain a larger recruitment pool, from which to draw the right skills in accordance with changes in technology.

However, greater mobility is accompanied by more pollution, congestion, noise, cost, and so on. But this is not infinite. Bertaud's one norm is that people should not (and if 'choice' were available, would not freely) commute for over an hour, per journey, to work. This hour might be $40 \mathrm{kms}$ on a train or $2 \mathrm{kms}$ on foot. Distance depends on mobility, and since the goal is to open up the widest possible jobs choice for all workers, commuter flow is the most important feature for the Labour Market. In history, those cities that secured mobility went on to a new round of growth and welfare. Those that did not, stagnated or declined into a congested and dysfunctional labour market. Contemporary notions of 'death-of-distance' or of digitally 'working-from-home', if taken too seriously in policy circles, risks stalling a city's economy for another round.

If mobility is critical to the functional city, how does Planning monitor or estimate it periodically? Sticking to simplicity, Bertaud suggests that the best way is to calculate the number of jobs reachable within 60 minutes from selected points. This would factor in transport mode, congestion, cost, distance, and routing. To generate an overall city mobility index, the various measures are weighted and summed. As any of these factors change (by transport investments, jobs redistribution, or naturally), the measure alerts us to a rise or fall in jobs reachable. The object of policy is to maximise the pool of jobs reachable from each point. With such a model not only can urban management track mobility (data allowing, even in real time), it can also test the consequence of various policy options such as increases in fuel cost; building a new freeway interchange, and using trains vs taxis as the primary mode for access to jobs. In all of this, a crucial feature is movement-space or room-to-move. How much space has been lost to illegal squatting in road/rail reserves in South Africa? What does that mean for mobility, now and in future in each city? The instinct is to build more and wider roads. While very important, other means Bertaud recommends carpooling, opening under-used bus lanes, parking tariffs, and so on. But what might they each contribute to aggregate urban mobility? It is never quantified as an index!

\subsection{Affordability}

A similar quantitative approach is proposed for the conversion of land into living and working space. Every family and firm is confronted with the same choice in respect of shelter or workspace. That is making a trade-off between rent, floor area, and location. ${ }^{7}$ The specific choice being made is what Bertaud views as the household's 'affordability'. This is in contrast to South Africa where 'affordability' is mostly regarded as a monetary threshold (incomes of <R3 500 per month, or R10 billion assigned for RDP houses annually), leaving us without a general indicator of urban affordability, per city. He recommends a simple 'price-to-income ratio' (PIR) index, to be maintained and monitored by Planning. This ratio is the median price of a dwelling to the median (annual) income of a household, in a said city. A ratio of $\leq 3$ is deemed

7 Obviously, when race-based policies, zoning restrictions, statutory plans, or density prescriptions are imposed, this decision process is curtailed or even nullified entirely. 
affordable. The vast majority of world cities have a much higher ratio; yet families falling below this index continue to live in said cities. How does this happen? The answer is densification. ${ }^{8}$ Families simply consume less living space (floor area) to cope with rents or move further away from high land prices. Once again, the 'land-consumption' process must not be impeded.

\subsection{Policy}

A lesson is that planners and urban policymakers must disabuse themselves of the notion that setting urban densities is a policy issue. It would be like trying to prescribe a ceiling to land-prices to ensure 'access' to the city. Like land prices, densities must be allowed to rise, fall and stay put according to the dynamics and demands set in the land-consumption process, per location. Any policy regulation on this matter will distort, or worse, stall the process. The same message applies for Floor Area Ratios. They are not independent norms to be set by policy, but signals subordinate to the demand and supply process allocating living and working space. If nothing else, permitting a third house on a single residential erf, 'as-of-right', is a densification victory for the market, not for the regulator. Empirical surveys have shown that land-use policy and urban edges invariably push the PIR index upwards.

Tracking a city's household income profile has a purpose other than to calculate the PIR. It can predict whether market pressure for densification is likely to be expressed vertically (higher rise walk-ups) or horizontally (infill squatting and dense informal areas). Medium-sized walk-ups will only be delivered if the median income rises, since land is 'capitalised' with loan funding to be repaid! If the median income drops (as urbanisation proceeds), the form of densification shall be horizontal, with implications for congestion and 'social unacceptability'. Since land and building cost play a vital role in

8 Densification in all variations of the term: building heights, cramped apartments, dense shacks, shared rooms. this instance, and since burdensome (or his 'binding' - p. 303) regulations push prices up, it is important to also maintain a property price profile for the city. If a real-estate market can supply living space cheaply and without encumbrance, then vertical densification is favoured. This has already been demonstrated in many well-located ex-RDP housing schemes.

This dynamic has been studied in considerable detail in Cape Town and South Africa, and so is well understood. The Integrated Human Settlements Framework (IHSF) $)^{9}$ concentrated specifically on quantifying the housing 'demands' of the lower-income segments of the population, while the Ease of Doing Business Survey (EdBS) ${ }^{10}$ was a comparison between South African cities in respect of their bureaucratisation, or red-tape imposed cost. In a further effort, it might be helpful to ascertain the precise share of property prices attributable to 'regulating', and what lifting them may contribute to realising the IHSF, via the market. The IHSF was heavily invested in the state as agent of housing supply.

\section{CONCLUSION}

In sum, Bertaud's message is: Rather than redesigning the city to meet its future needs, resort to quantified monitoring. In that endeavour, the state must retreat from participating in the marketplace (building houses; setting density targets, and so on) and start using software tools to track 'labour-market' performance, the efficacy of the 'land-consumption' process, and 'mobility levels' in our cities. The processing software is available by now; the information sources and data are at hand. Bertaud gives us the mathematical formulae and theories to do the job. Within Planning, a transition from Design to Technology is now critical, much like the transition from horse-drawn cart to motor vehicle was essential to the ongoing productivity of ever-growing cities.

9 Integrated Human Settlements Framework 2015. City of Cape Town.

10 https://www.doingbusiness.org/en/data/ exploreeconomies/south-africa 